\title{
Avrupa Birliği Göç Politikaları ve Göçmenlerin Sosyal Olarak İçerilmelerine Etkisi
}

\author{
Orhan KOÇAK ${ }^{1}$ \\ R. Demet GÜNDÜZ ${ }^{2}$
}

\section{Özet}

Avrupa Birliği kurulduğundan beri başka ülkelerin vatandaşları için cazibe merkezi olmuştur. Avrupa Birliği'nin geçirmiş olduğu aşamalar neticesinde, sadece ekonomik, sosyal ve siyasi olarak değil demokratik olarak da rol model olabilecek seviyeye ulaşmıştır. Gelinen gelişmişlik seviyesi sayesinde, Avrupa Birliği gerek çekici gerekse itici sebeplerden dolayı başka ülkelerden sürekli olarak göçlere maruz kalmıştır. 1960'lar sonrasında ekonomik nedenlerle Avrupa Birliği ülkelerine göç edenlerin büyük bir kısmı, o ülkelerin vatandaşlığına geçmişlerdir. Bununla birlikte, Birlik ülkelerine ekonomik ve siyasi nedenlerden dolayı yeni göçler olmaktadır. Göçle ve göçmenlerin ekonomik ve sosyal olarak içerilmeleri (entegrasyonları) ile ilgili Avrupa Birliği ülkelerinin her birinin kendi mevzuat ve uygulamaları olmasının yanında, Birlik çapında da ortak düzenlemeler ve uygulamalar zaman içerisinde ortaya çıkmaktadır.

Bu çalışma ile Avrupa Birliği'nde yaşayan ve hala bölgeye gelen göçmenlere yönelik içerme politikalarının neler olduğu ve etkilerinin hangi boyutta olduğu incelenmiştir. Çalışma üç bölümden oluşmaktadır. İlk bölümde genel olarak Avrupa Birliği’nin karșılaşmıș olduğu göçle ilgili olarak tarihsel süreç irdelenmiştir. İkinci bölümde ise, Avrupa Birliği düzeyinde sosyal içerme politikaları ve son bölümde ise bazı üye ülkelerde göçmenlerin entegrasyonu amacıyla yapılan düzenleme, uygulama ve yaklaşımlar incelenmiştir.

Anahtar Kelimeler: Avrupa Birliği, Göç, Sosyal Dışlanma, Entegrasyon

\section{Immigration Policies of European Union and It's impact to Social Inclusion of Migrants}

\begin{abstract}
European Union has become a charming center for the citizens of other countries since it was established. European Union has reached a level where it is seen a role model not only economic, social and political but also democratic in the wake of some challenges. Because of the level of development the Union came, it is continuously exposed to immigrants from other countries. Majority of the immigrants who migrated to Europe because of economic reasons after 1960s became the citizens of Europe Countries. Besides, The Union Countries has been attracting new immigrants since economic and political reasons. With these developments, European Union countries has been confronting new challenges and trying to solve them. Especially, integration policy of socially and economically excluded immigrants is becoming more important day by day. For this reason, some regulations has been constituting both at the level of European Union and the member countries in order to converge different legal implementations.

With this study, it was studied that what are the inclusive policies towards socially and economically excluded immigrants who came before and are still coming to European Countries. This study is divided into 3 parts. In the first part, the literature about historical process of European Union immigration is reviewed. In the second part, the policies of social inclusion of European Union and in the third part, regularities, implementations and approaches in order to integrate of immigrants in some countries of the Union are studied.
\end{abstract}

Keywords: European Union, Immigration, Social Exclusion, Integration

1 Doç. Dr., İstanbul Üniversitesi, Sağlık Bilimleri Fakültesi, Sosyal Hizmet Bölümü, orhan.kocak@istanbul.edu.tr

${ }^{2}$ Uludağ Üniversitesi, Sosyal Bilimler Enstitüsü Doktora Öğrencisi, rdmtgndz@gmail.com 
Yalova Sosyal Bilimler Dergisi

\section{Giriş}

Göç konusu yol açtığı etkilerden dolayı, dünyanın en önemli konularından biri olmaktadır. Göç konusu, nedenleri ve sonuçları itibariyle çok boyutlu olarak değerlendirilmesi gereken bir sosyal sorundur. Neden ve sonuçları yanında etkilediği toplumlar açısından da tartışılması gereklidir. Göç sadece göç edenleri değil, göç edilen yerde bulunan yerleşik toplumları da etkilemektedir. Aslında pek de gündemde olmayan, fakat diğerleri kadar önemli olan, kaynak ülkenin toplumlarının da göç sürecinden etkilendiği söz konusudur.

Ailelerin dağılması, toplumsal bağların kopması, emek piyasalarının etkilenmesi, işgücü göçü, beyin göçü, eğitim ve mesleki gelişim, ayrımcılık, katılım, dini ve kültürel çatışmalar ve birçok durum göç ve göçmen konusu ile ortaya çıkmaktadır. Avrupa Birliği'nin $(\mathrm{AB})$ ekonomik ve sosyal olarak cazip bir bölge olması nedeniyle, gelişmekte ve az gelişmiş olan ülkelerden gelen göçmenler için sürekli bir ümit kapısı olmuştur. Önceleri işgücü ihtiyacını karşılamak amacıyla kontrollü kabul edilen göçmenler, sonraları kontrol dışına çıkarak her $\mathrm{AB}$ ülkesi için sıkıntılı olmaya başlamıştır. Böylece her üye ülke kendi düzenlemelerini yapmaya gayret ederken, $\mathrm{AB}$ çapında da ortak politikaların yapılması yönünde çabalar olmuştur.

Avrupa'nın çoğunluğunu Suriye iç savaşından kaçanların meydana getirdiği ve AB'nin politikalarını sıkıntıya sokacak derecede tüm ülkeleri etkileyen ani göç dalgası, Avrupa'ya sıkıntı yaşatmaktadır. Bu göç dalgası göstermiştir ki, Avrupa ve uluslararası toplum büyük sayıdaki göç dalgalarına hazır değildir. Zor durumda kalan göçmenleri koruyacak yeteri kadar sistemlere ve altyapıya sahip olmadıkları anlaşılmıştır. Böyle bir altyapının olmaması nedeniyle, popülist söyleme sahip olan liderlerin bu açıkları kullanarak, uzun yıllar boyunca temelleri ve üst yapısı oluşturulan liberal-özgürlükçü ve hoşgörülü olan toplumu olumsuz yönlendirdikleri görülmektedir.

Akdeniz ve Ege Denizi üzerinden canlarını tehlikeye atarak Avrupa'ya geçen göçmenlerin 4000 kadarı hayatlarını kaybetmiştir (The Economist, 2016). Üstelik Avrupalı resmi görevliler mağdur durumda olan bu insanlara destek vermedikleri gibi, onları ölüme terk edecek yaklaşımlar sergilemişlerdir. Bu tür yaklaşımlar, bir başka yönüyle bakıldığında Avrupa'nın geldiği hatalı durumu gözler önüne sermektedir. Halen Macaristan ve Polonya'da iktidarda bulunan göçmen karşıtı olan partilerin söylem ve politikaları, diğer ülkelerde 1lımlı olan politikacıları da göçmen karşıtı politikaları benimsemeye mecbur bırakmaktadır. Bu yaklaşım Avrupa içerisinde göçmen politikaları konusunda işbirliği imkânlarını olumsuz etkilemektedir. Bu süreç, Avrupa'nın dış dünyada daha şövenist ve beceriksiz olduğu kanaatini de oluşturmaktadır. Yaşananlar, AB'de göç konusunda önemli değișimlere neden olacak sıkıntıların ortaya çıkmasına neden olmuștur. Böylece, AB'nin önemli bir altyapısı olan Schengen vize sisteminin sorgulanır hale gelmesi, sadece göç politikalarını etkilemekle kalmamış, ayrıca Birliğin ekonomik, sosyal, siyasi ve özgürlüklere bakışını tehdit eder hale gelmiştir. Dolayısıyla AB'nin özgürlükçü bakış açısıyla var olan göçmenlerin her yönüyle daha fazla entegrasyonu ve içerilmeleri beklenirken, tam tersi gelişmelerin olması ve ayrıca gelen göçmenlere uluslararası sözleşmelere aykırı davranışlar sergilemeleri Birliğin geldiği durumun vahametini göstermektedir. 
Yalova Sosyal Bilimler Dergisi

\section{Avrupa Birliği Göç Politikaları}

Avrupa'ya göç dalgaları II. Dünya savaşı sonrasında ortaya çıkmaya başlamıştır. Savaş sonrasında birçok genç insanın hayatını kaybetmesi her sektörde büyük bir açık yaratmıştır. Almanya, Fransa, Belçika ucuz iş gücü için güney Avrupa, Türkiye ve Kuzey Afrika'dan işçi kabul etmiştir. Birçok yabancı işçi, 'misafir işçi' olarak karakterize edilmiş ve geçici olarak ikamet edilecekleri düşünülmüştür. İngiltere, Fransa ve Hollanda daha çok kendi kolonilerinden göçmen işçi almışlardır. İtalya ve İspanya onları örnek almışlar ve tarımsal bölgelerden işçiler getirmişlerdir. İstihdam krizi çok büyük boyutlara ulaşmış ve bu nedenle göçmen işçiler Avrupa'nın tekrar kurulmasının aracı olarak görülmüştür. 1970'lerde OPEC'in uyguladığı petrol ambargosu, küresel durgunluğa yol açmış ve işsizlik hızlı bir şekilde artmaya başlamıştır. Bu süreç yerel halkın işlerini kaybetmemek için göç karşıtı politikaları desteklemesine neden olmuştur.

Avrupa'da göç 1980'li yıllarda, birçok yeni karakteristik özellik sergilemiştir. Bu dönemde sığınmacı sayılarının çok büyük rakamlara ulaşması, yasadış1 göç ve aile birleşimi trendlerinin oluşmasına da neden olmuştur. $\mathrm{Bu}$ döneme kadar Kuzey Avrupa'da yoğun olarak işgücü piyasasında vasıfsız işgücü boşluklarını dolduran göçmenler 1980'lere gelindiğinde Güney Avrupa'ya da yönelmeye başlamıştır (Penninx, Spencer and Hear, 2008).

AB ülkelerindeki yabancı işgücü sayısı 1980'lere kadar her yıl artış göstermiştir, ancak yabancı işgücü alımına sınırlama getiren kanunların yürürlüğe konmasıyla birlikte işçi sayısında azalma görülmeye başlamıştır. Bu azalmanın bir diğer sebebi de göç için yeterli altyapısı bulunmayan Avrupa'da, büyük meblağlarda kara para döngüsü ortaya çıkaran kayıt dışı istihdam ve yasadışı göçü engellemeye yönelik olarak, göçmenlerin yasallaştırılması sürecine girişilmiştir. Ancak bu süreçte yasallaştırılan göçmenlerin çoğunluğu çeşitli nedenlerle yeniden yasadışı olmuşlardır. Fakat bu süreç özendirici olmuş ve yasadışı göçü daha da tetiklemiştir (Baldwin ve Edwards, 1992: 30-32).

Soğuk Savaşın sona erdiği ve Doğu Bloku'nun yıkıldığı 1990'lı yılların başına kadar Avrupa Birliği bölgesel nüfus kontrolü politikalarını uygulama imkânı bulmuştur. Bu dönemde ekonomik ve siyasi birlik kriterleri, özellikle Batı ve Orta Avrupa'da büyük sorunlarla karşılaşılmadan sürdürülebilmiştir. 1990'lı yıllardan itibaren, büyük boyutlarda olmasa da Avrupa Birliği ülkelerine yeni göç hareketleri başlamıştır. En yüksek oranda göç akışı 1992 yılında gerçekleşmiş ve İspanya, Portekiz ve İtalya dış göç alırken, Almanya da en fazla iltica başvurusu alan ülke olmuştur (Hermann, 1993: 4-5). Bu dönemde milyonlarca kişiye varan göç hareketi yaşanmış ve göçmen kaçakçılığı, uluslararası bir kazanç alanına dönüşmüştür (Salt ve Stein, 1997). Bu gelişmeler 1şığında Avrupa Birliği'nin göç politikaları günümüz itibarıla değerlendirildiğinde, özellikle 1990 sonrası dönemde göç olgusu konusunda bir ikilem içerisinde kalındığı görülmektedir. Avrupa Birliği bir yandan demokratik değerler ve insan haklarının, diğer yandan ise milli egemenlik, güvenlik ve ekonominin bulunduğu bir platformda, uluslararası göç konusunda denge arayışına girişmiş ve bu bağlamda yaşanabilecek yeni göçleri engellemek adına önlemlerini arttırırken, mevcut olan göçmenlerin entegrasyonunu sağlamak için de politikalar üretmeye çalışmıştır (ABKDBB, Haziran 2006: 1-3). 
Yalova Sosyal Bilimler Dergisi

Sovyetlerin çökmesi ve Berlin duvarının yıkılması ile başlayan sürecin sonunda göç tekrar hız kazanmıştır. Avrupa komisyonunun açıkladığ raporlara göre 19 milyon göçmen, yani bir diğer ifadeyle 15 üye ülkenin nüfusunun \%5.1'i Avrupalı değildi. Yine 2002 yılında yapılan bir çalışmaya göre Almanya'nın \%7'si Fransa'nın ve İsveç'in \%6'sı göçmenlerden oluşmaktaydı (European Comission, 2002: 4).

$\mathrm{AB}$ üye ülkelerinin ekonomik büyümelerinde son y1llarda yavaşlama olmasına rağmen, istihdam ilişkili işgücü göçü artışına neden olan birkaç faktör bulunmaktadır. Bilgi ve iletişim teknolojileri, sağlık ve eğitim alanlarında nitelikli insan gücüne talebi olan üye ülkeler, bu niteliklere sahip yüksek nitelikli insan gücünü kendi ülkelerine çekebilmek için ikamet ve istihdamda kolaylık sağlayıcı yasal düzenlemelere gitmektedirler (Gençler, 2005, 182). Dolayısıyla her ülkenin göçmenlerle ilgili kendilerine has yasal düzenlemeleri de ortaya çıkmıştır. Bunun yanında, Avrupa Birliği ekonomik ve siyasi bir dönüşüm yaşaması ile birlikte Birliğin bütünlügünü sağlayacak ve gerek iç gerekse dış göçü kontrol altında tutacak düzenlemeler yapmaya gayret etmiştir. $\mathrm{Bu}$ anlamda farklı dönemlerde Birlik düzeyinde farklı anlaşmaların yapıldığı görülmektedir.

Tablo 1: AB Göç Politikalarını Etkileyen Antlaşmalar

\begin{tabular}{|c|c|}
\hline Yapılan Anlaşma ve Tarihi & Yapılış Nedeni \\
\hline Schengen Anlaşmas1: 1985 ve 1999 & Serbest Dolaşım İlkesi \\
\hline Dublin Konvansiyonu: 1990 & Sığınmacıların Statüsü \\
\hline Maastricht Antlaşması: 1993 & $\begin{array}{l}\text { Üç Sütunlu Yapıda Göç Politikası } \\
\text { (adalet ve içişleri, sığınma politikası ve } \\
\text { göç politikası) }\end{array}$ \\
\hline Amsterdam Antlaşması: 1997 & Maastricht Sonrası Düzenlemeler \\
\hline Tampere Zirvesi: 1999 & Göçmen Akışının İdaresi \\
\hline Temel Haklar Şartı: 2000 ve 2009 & $\begin{array}{l}\text { Medeni, Siyasi, Ekonomik ve Sosyal } \\
\text { Haklar }\end{array}$ \\
\hline Seville Zirvesi: 2002 & $\begin{array}{l}\text { AB Göç Politikasının Kaynak ve } \\
\text { Transit Ülkelere Genişletilmesi }\end{array}$ \\
\hline Nice Antlaşması: 2011 & $\begin{array}{l}\text { Göç Alanında da Nitelikli } \text { Oy } \\
\text { Çoğunluğu }\end{array}$ \\
\hline Avrupa Anayasası Antlaşması: 2004 & Ortak Göç Politikaları \\
\hline Avrupa Göç ve Mülteci Paktı: 2008 & Avrupa için Ortak Göç Politikası \\
\hline $\begin{array}{l}\text { Hague ve Stockholm Programı: } 2004 \text { ve } \\
2009\end{array}$ & Geleceğe Yönelik Adımlar \\
\hline Lizbon Antlaşması: 2009 & $\begin{array}{l}\text { Gelinen Son Nokta (dış sinır } \\
\text { denetimleri, iltica, göç, suçun } \\
\text { önlenmesi, serbest dolaşım, iç, } \\
\text { sınırların olmadığı bir özgürlük ve } \\
\text { güvenlik alanı sunumu) }\end{array}$ \\
\hline
\end{tabular}

Kaynak: Değirmenci, Gamze, Avrupa Birliği Göç Politikası Kapsamında Fransa’nın Göç Politikası İstanbul Üniversitesi, Sosyal Bilimler Enstitüsü Avrupa Birliği Ana Bilim Dalı, Yüksek Lisans Tezi, İstanbul 2011 (Yazar tarafindan derlenmiştir). 
Yalova Sosyal Bilimler Dergisi

$\mathrm{AB}$ içerisinde her devlet Birlik mevzuatına uygun olmayan bir eylemde bulunduğunda kendi ulusal mevzuatını ileri sürerek politikasını meşrulaştırabilmektedir. Avrupa Birliği'nin göç politikası baz alındığında Birlik içinde bu tarz bir yaklaşım ortak uzlaşının sağlanmasını güçleştirmektedir. Üye ülkelerin yürürlükte olan yasaları ve düzenlemeleri $\mathrm{AB}$ mevzuatı ile birebir örtüşmese bile politikalar arasında en azından uyumun sağlanması önemlidir. $\mathrm{Bu}$ uyum Birliğin dışarıya karşı izleyeceği politikalarda da sesinin daha etkin çıkmasını sağlayacak ve elini güçlendirecektir (Değirmenci, 2011: 96). AB ülkelerinde mevcut demografik durumun bir bakıma göç politikasını zorunlu kıldığı göz önünde bulundurulursa, Lizbon Antlaşması ile göç konusunda yetkili olan Birliğe fazlaca görev düşmüştür (Karaşahin, 2012: 133).

Aslında Avrupa Birliği, mevcut cazip yapısıyla uluslararası göç hareketlerinde en önemli çekim merkezleri arasında olmuştur. Ancak, Avrupa Birliği'nde dâhili sınırların kaldırılması sonrası üye ülkeler, mülteciler ve göçmenlerin kontrolünü sağlamak amaciyla ortak bir tutum içerisine girmek zorunda kalmışlardır (Tekin, 2009: 69). Fakat bu amaçla AB içerisinde onaylanan 25 Eylül 2008 tarihli Göç ve İltica Avrupa Sözleşmesi, politik bir belge olup yasal bağlayıcılığı yoktur. $\mathrm{Bu}$ sözleşme, göç yönetiminde yeni politikalara canlılık getirme amacındadır. Göçmenler AB'nin rekabet stratejisinin vazgeçilmez bir parçasını oluşturmanın yanında, ev sahibi topluma ve ekonomiye entegre olma imkânı verilmeden potansiyelleri ortaya çıkmayacaktır. Yasal yollardan ikamet almış göçmenlerin entegrasyonu, öncelikli bir süreç olmanın yanında $A B$ 'nin göç politikasında önemli bir bileşendir. Entegrasyon planı, bir taraftan ev sahibi toplumda göçmenler için haklara ve firsatlara erişim sağlama yönünde politikalar geliştirirken, diğer taraftan entegrasyonla göçmenlerin ev sahibi toplumun yasaları, kurumsal yapısı, değer yargıları ve prensipleriyle kabullenilmesini kapsamalıdır (Tekin, 2009: 79).

$\mathrm{AB}$ ülkelerinin göç ve iltica politikaları kabaca iki aşamaya ayrılabilir. Birinci safha, göçmenlerin ve iltica arayanların sayısını sınırlandırmak ve müracaatçıları iltica talep etmekten caydırmak için tasarlanmış milli politikalardır. $\mathrm{Bu}$ politikalar birbirleriyle koordineli değildir. İkinci safha, entegre edilmiş ve koordine edilmiş bir Avrupa göç ve iltica politikasının takdim edilmesiyle başlamıştır. Göç politikalarının bu şekilde "Avrupalılaştııılması" iki ana hedef tarafından teşvik edilmiştir. Birincisi, göçmenlerin sayısında meydana gelebilecek herhangi bir ilave artışı kontrol etmek ve sınırlandırmak ve tek taraflı göç yönetiminin sebep olacağı olumsuz etkilerden kaçınmak iken, ikincisi AB'ye üye olan devletler arasındaki sınır kontrollerinin kaldırılmasına yol açacak tek bir Avrupa Pazarı'nı gerçekleştirme girişimlerine hazırlanmaktır (Bingöl, 2006: 47).

Bir diğer taraftan, son yıllarda görüldü ki, göç sadece kaynak ya da gidilen ülkelerin sorunu değildir. Yani, göç edilen ülkelerin yöneticileri aşırı göçler nedeniyle ve ortaya çıkan baş edilemez sıkıntılar yüzünden, göç edenlerin kaynak ülkelerinde de var olan sorunları azaltmaya yönelik politikaları gündemlerine almaya ve soruna çok daha geniş perspektiften bakmaya başlamışlardır (The Economist, 2016). Bu anlamda, ilk olarak kaynak ülke ve komşu ülkelerdeki göçmenlere yönelik çalışma, eğitim ve sağlık imkânlarının geliştirilmesi önemlidir. İkinci olarak ise, $\mathrm{AB}$ tarafından sığınmacıların taleplerinin zamanla alınması ve son 
Yalova Sosyal Bilimler Dergisi

olarak ise, göçmenlerin mobilitesinin engellenmesi veya bulundukları yerlerde kalmalarının teşvik edilmesi için politikalar üretilmelidir (Sutherland, 2016).

\section{Avrupa'da Göç ve Sosyal İçerme Politikaları}

Göç önüne geçilemez bir durumdur ve devletlerin yapacağı en iyi şey göçmenler ve yerel halk için olumlu sosyo-ekonomik sonuçları elde edebilecek bir etki oluşturmaktır. Bununla beraber toplum içerisinde en zayıf halka olan göçmenlerin sosyal olarak içerilmeleri başılı başına bir politika olarak ortaya önemlidir. Bu politikanın yarattığı koşullar insanların azınlığa mı yoksa çoğunluğa $\mathrm{m} 1$ ait olduğunu belirlemede rol oynayarak sosyal harmoniyi sağlayacaktır.

AB üye ülkelerinin ulusal göç politikaları, sadece kendi sınırları içerisinde etkili olmamakta, sınırlarını aşarak süratle diğer ülkeleri de tesiri altına almaktadır. Üye ülkeler yürüttükleri farklı türden göç politikalarını hâlihazırda birbirleriyle paylaşmaktadırlar. Kimi üye ülkeler çok kültürlülükten bahsederken kimileri kültür mozaiğinden bahsetmektedirler. Mevcut göç politikaları üye ülkelerin ulusal çıkarlarını yansıtmakta ve hiçbir sistem aslında sonuç olarak diğerine benzememektedir (Tekin, 69, 2009). Aşağıdaki tablo bazı AB ülkelerinin şehircilik anlamında entegrasyon politikalarına yönelik düzenlemelerini göstermektedir. Dolayısıyla entegrasyon politikalarının yeknesaklığından bahsetmek mümkün değildir.

Tablo 2: Farklı AB Ülkelerinde Şehircilik Anlamında Entegrasyon Politikaları

\begin{tabular}{|l|l|l|}
\hline Ülke Adı & Uygulanan Politikalar & Yıl \\
\hline Fransa & Yerel sosyal kalkınma politikası & 1982 \\
& Şehir sosyal kalkınma politikası & 1988 \\
& Şehir için politika & 1990 \\
& Hassas şehir bölge politikası & 2003 \\
\hline Hollanda & Toplanma yerleri sorunları için politikalar & 1985 \\
& Sosyal yenilenme politikaları & 1990 \\
& Büyük şehir politikası & 1994 \\
& Bölgesel yenilenme politikası & 2007 \\
\hline İngiltere & İskoçya şehir yaşam politikası & 1988 \\
& Topluluk programı & 1988 \\
\hline Almanya & Sosyal Şehir & 1999 \\
& Ulusal şehir kalkınma politikası & 2007 \\
\hline İsveç & Gelişmemiş bölgelerin kalkınması & 1995 \\
\hline Belçika & Sosyal kalkınma fonu & 1996 \\
& Büyük şehirler politikası & 2000 \\
\hline
\end{tabular}

Kaynak: Uitermark, Justus, Integration and Control: The Governing of Urban Marginality in Western Europe, International Journal of Urban and Regional Research 38.4, Volume 38.4 July 2014, 1424.

$\mathrm{AB}$ ülkelerinin göç konusunda öncelikli kaygıları $\mathrm{AB}$ topraklarına girmeyi başarmış ilticacıların durumlarını ele alacak bir sistem geliştirmek ve iltica 
Yalova Sosyal Bilimler Dergisi

taleplerine ilişkin birlikte kabul edilmiş prosedürler meydana getirmek olmuştur. $\mathrm{Bu}$ amaçlarını uygulamak için kullandıkları kavramlarda Schengen Antlaşması ve Dublin Antlaşması'dır. Yine bu ülkelerin diğer bir temel kaygısı ise üye devletlerdeki göçmenler için kısıtlayıcı tedbirler uygulamak ve $A B$ düzeyinde gerçekleștirilecek politika koordinasyonunun yöntemini geliştirmektir. Ancak bu tedbirler esas olarak, $\mathrm{AB}$ dışında kararlaştırılacak fakat $\mathrm{AB}$ düzeyinde koordine edilecektir. Dolayısıyla Avrupa politikası millet-üstü bir nitelikte değil, hükümetler arası bir niteliktedir (Bingöl, 2006: 47).

Göçmenlerin entegrasyonu, göçmenin yeni bir toplum içerisine ulaştı̆̆ gün başlamaktadır. Hükümetlerin seçtiği yaklaşım, göçmen entegrasyonun ve hizmetlerinin çıktılarını belirlemektedir. $\mathrm{Bu}$ süreç beraberinde bireysel olarak göçmenin entegrasyonunu etkileyecektir. $\mathrm{O}$ nedenle göçmen entegrasyonu, hem dahil olunan toplumları hem de göçmen birey ve toplumların taleplerini dikkate almalıdır (Ecre, 2016). Ancak, göçmenlerin düzenli toplumlardan farklı olarak kendilerine has olan belirli ihtiyaçlarının olmasıdır. İlave olarak daha kırılgan olmaları da göz önünde bulundurulmalıdır. Dolayısıyla, ana akım politikalar içerisinde olacak entegrasyon politikalarında göçmenlerin özel ihtiyaçları kabul edilmiş olmalıdır.

Küreselleşmenin ile toplumların kendi kültürünü ve geleneklerini korumaları artık çok kolay değildir. Kültürel ilişkilere girmek yeni bir grup kimliği oluşturmakta ve yeni bir kültür, gelenek ve var olma yolu açmaktadır. Sadece Avrupa alt kültürlerini uyumlaştırmak ve ortaya çıkan her türlü farklılığ yönetmek yasal ve kurumsal açıdan yeterince zor olmaktadır. Genellikle, yerel topluluklar, göçmenleri önemli bir kültürel, sosyal ve ekonomik tehlike olarak görmektedirler. Önemli miktarda göçmen yasa dışı işler yaptıklarından dolayı hapse girmişlerdir. Almanya'da yabancılar halkın \%9'unu temsil ederken suç oranının \%33'ünü temsil etmektedirler. Yine Fransa'da yabancilar \%8 nüfusa sahip olmalarına rağmen, suçluluk oranları \%26 seviyesinde olmuştur (Fuller, 2002: 5).

Suç oranlarının bu denli yüksek olmasının sebebi işsizlik oranları ile alakalıdır. Almanya'da Alman orijinli vatandaşlar içinde çalışabilecek olanların işsizlik oranı \%7 iken, göçmenler arasında çalışabilecek olanlarda işsizlik \%15'dir. Fransa' da bu oranlar Fransız orijinli vatandaşlarda \%9 göçmenlerde ise \%20 olarak gözükmektedir. Avrupa Komisyonu'nun yaptığı bir ankette halkın \%37'si işleri olmayan ve uzun süreli işsizlik ödeneği alan göçmenlerin ülkeden gönderilmeleri gerektiğini savunmuştur (European Comission, 2002). Buna karşın göçmenler ise işsizliklerinin sebebi olarak, bazı sektörlere alınmamalarını ve özellikle tercih edilmemelerini göstermektedirler. Fransa örneğinde, göçmenler hava yolları pilotu, eczacı, mimar gibi birçok işte çalışamazken, aynı zaman da alkol ve sigara satışı için gerekli belgeleri de alamamaktadırlar. Benzer kısıtlamalar diğer Avrupa Birliği ülkelerinde de mevcuttur. 2002 de yapılan çalışma, halkın çoğunluğunun göçmen baskısının katlanılabilir ölçüyü aştığını göstermektedir (Nyberg-Sorenson, Van Hear ve Engberg-Pedersen, 2002: 5).

Yaşanan göçlerden sonra oluşan tecrübeler, bazı fikirlerin kristalleşmesini de sağlamıştır. Böyle bir tecrübe, göçmenler için en azından 3 ana konuda sosyal içermenin değerlendirilmesini gerektirmektedir. Bunlar kısaca, göçmenlerin yerel halk tarafından kabul edilmesi, yerel halkın göçmenler tarafindan kabul edilmesi ve 
Yalova Sosyal Bilimler Dergisi

bu iki topluluk hatta devlet ve kamu otoriteleri arasında nitelikli bir iletişim stratejisinin olmasıdır. Özellikle bu son konuda mutlak kuralların konulması ve iletişimin ihlal edilen ve beklentilere uymayan yollarla olmasının önüne geçilmesi gereklidir. Örneğin Fransız halkı, göçmenlerin istihdam ve sosyal güvenlikle ilgili sorunlarının en önemli kaynağı olduğuna inanma eğilimindedirler.

İngiltere, Hollanda ve Almanya'da bulunan göçmenlere yapılan testler ise onların daha fazla belli konulara odaklanmalarına yardımcı olmaktadır. Entegrasyon testi vatandaşlık almadan önce yapılıyor, kişilerin Avrupalı olup olmadıklarını, yeterince batılı düşünüp düşünemeyeceklerini ölçmek amaçlı yapılmaktadır (Snyder, 2006: 25). Çok kesin şekilde bu sonuçlara varabilecek netlikte sorular bulunmaktadır. Ancak yapılan testler, Hollanda haricinde çok kültürlülüğün yaygınlaşmasından daha çok, tek kültürlülüğün yerleşmesine ve entegrasyondan daha ziyade kısmen asimilasyona neden olmaktadır. Her üç ülkenin de ortak noktası varılan ülkenin yaşayış tarzının ve değerlerinin kabul edilmesinin talep edilmesidir. Soruların göçmenlerin günlük hayatında kolaylık yaratmaktan uzak oldukları da tartışma konusudur. İngiltere'nin sınavı Almanya ve Hollanda'nınki gibi bir kültür sınavı değil bir vatandaşlık bilgisi sınavıdır. Kișinin kültüre değil de vatandaş olarak rollerine uyum sağlaması amaçlanmaktadır (Snyder, 2006: 49).

$\mathrm{Bu}$ sinavlar ve materyallerden anlaşılan, batılı ülkelerin göçmenlerden taleplerde bulunabilmek konusunda daha da güçlenmiş olduklarıdır. Kendi ülkeleri açısından uyumsuz gördükleri şeyleri kabul etmemek konusunda daha güçlü ve çok kültürlülükten kültürel asimilasyona değişen ideolojik bir değişikliğin oluştuğu bir kabul söz konusudur. Bu sınavlar, Müslümanları ve Batılı olmayanları genellikle kendi önyargıları ile sinıflamakta ve liberal demokratik bir topluma uyum sağlayamayacakları ön kabulüyle hazırlanmaktadırlar. Ayrıca bu ülkeler göç alan ülkenin yaşayış şeklini ve değerlerinin kabul edilmesini de zımnen talep etmektedirler. Bu talep sonucu gerçekleşen değişim, büyük bir ideolojik dönüşüm ve zorla kabullenilmeyi sağlamaktadır. Dolayısıyla entegrasyon politikaları genel olarak, çok kültürlülüğü öne çıkarmaktan daha çok kültürel asimilasyona doğru bir değişimi temsil etmektedir (Snyder, 2006: 50).

Genel olarak AB seviyesinde, göçmenler için gerçekleştirilen programları, yerel seviyede politik katılım, vatandaşlık kazanımı, aile birleşimleri, emek piyasasına erişim, barınma ve misafir toplumun kültürel değerlerinin korunması olarak sıralanabilir. Entegrasyon politikalarının yoksunluğu, AB'nin Avrupa içinde yerleştirmek istediği eşitlik, demokratik temsil ve sosyal uyum gibi değerlerin yıpranmasına yol açacaktır. Avrupa Parlamentosu ise bu sürecin iyi işlemesi amacıyla, ülkelerin entegrasyona dair gönüllü sektörler, toplumsal kuruluşlar ve göçmenlerden oluşan birimlerin koordinasyon içerisinde çalışmasını desteklemektedir (Tekin, 2009: 89). Göçmenleri içerme konusu genelde ekonomik olarak değerlendirilmiş ve ona göre politikalar üretilmiştir. Ancak göçmenlerle ilgi olarak ev sahibi toplumun en çok sorun yaşadığı alan ekonomi dışı konular olduğu anlaşılmıştır. Dolayısıyla ekonomik entegrasyona ilave olarak kültür, dil, eğitim ve önyarg1 gibi konuların da gündeme alınması gerekmektedir. Aşağıdaki tabloda entegrasyonun kültürel boyutunu öne çıkaran yaklaşımlar görülmektedir. 
Yalova Sosyal Bilimler Dergisi

Tablo 3: Entegrasyon Sürecinde Önemli Yaklaşımlar

\begin{tabular}{|l|}
\hline Entegrasyonun bir proje olarak değil bir süreç olarak görülmesi \\
\hline $\begin{array}{l}\text { Pozitif rol modellerin varlı̆̆ı ve önyargı ve basmakalıplar ile } \\
\text { mücadele edilmesi }\end{array}$ \\
\hline Mesleki dil ve uygulama eğitiminin sağlanması \\
\hline $\begin{array}{l}\text { Toplum içerisinde kültürlerarası gerçeklik algısının } \\
\text { güçlendirilmesi }\end{array}$ \\
\hline Kültürlerarası eğitimin desteklenmesi ve yaygınlaşması \\
\hline Çok dilli eğitimin yaygınlaşması \\
\hline Entegrasyon sürecinde dil ve dinin rolünün kabul edilmesi \\
\hline $\begin{array}{l}\text { Entegrasyon sürecinde kültürel odaklanmanın ekonomik } \\
\text { odaklanmanın önüne geçmesi }\end{array}$ \\
\hline Entegrasyonun iki boyutlu bir süreç olduğunun kabulü \\
\hline
\end{tabular}

Kaynak: Berlinghoff, Marcel, Migration and Cultural Integration in Europe, ifa-Edition Culture and Foreign Policy, Conference Report, Brussels, 11 December 2013, s 3-15

$\mathrm{AB}$ devletleri arasında hala var olan farklılıkları azaltıcı uyumlaştırıcı entegrasyon politikalarına rağmen, Avrupalı politikacılar göçmenleri ve azınlıkları, halklarının içerisine entegre etmek amacıyla bireyi önceleyen güçlü neo-liberal devlet anlayışını (muscular liberalism) öne çıkararak "çok kültürlülüğün sonu" tartışmalarını gündeme getirdiler. Bu durum, entegrasyon politikalarında ekonomik olandan kültürel odaklanmaya evrilen bir değişime neden olmuştur. Yıllarca göçmenlerin kendi kendilerine yetmesi gerektiği beklentisi vardı. Günümüzde ise yeni gelen göçmenlerden yeni beklentiler söz konusudur. Bu süreç, her ülkenin politikalarının farklılaşmasına neden olmuştur. Almanya'da dil öğrenimi ve ülke hakkında temel bilgilerin kazanımına odaklanma söz konusu iken, Fransa'da dil bir sorun olarak görülmemiştir. Daha ziyade, Fransız kültürü ile uyumlu olan tutum, davranış ve değerler görülmektedir. Hollanda'da "kalben Hollandalı" olmayı öne çıkaran kültürel entegrasyon benimsenirken, aksine İngiltere'de öğrenilen kültürün uygulamaya yansıması önemsenmektedir (Berlinghoff, 2013: 10).

Son yıllarda Avrupa'da aktif entegrasyon politikaları kayda değer bir şekilde hayata geçirilmeye başlanmıştır. Bu politikalar, farklı açılardan, sosyal, kültürel ve ekonomik hayatın firsat ve şans eşitliğini artırmayı, profesyonel eğitim ve sosyal hizmetlere ulaşımı, sosyo-kültürel entegrasyonu ve sivil katılımı amaçlamaktadır. Pozitif etki yaratan projeler de öne çıkmış olup, farkındalığ artırıcı ve insanlara farklılıkları yönetmeyi öğretici özel eğitimler de öne çıkmıştır. Eşitliği artırıcı ve suçla mücadeleyi destekleyici kişilik oluşturma yönünde çalışmalar söz konusudur. Tüm bu amaçlara ulaşabilmek için, AB düzeyinde özel Aksiyon Programı tüm üye ülkelerin katılımıyla sağlanmıştır. 
Yalova Sosyal Bilimler Dergisi

Avrupa Birliği'nde üye ülkeler politika ve stratejilerini halkın ihtiyaçları ve gereklilikleri doğrultusunda belirleyebilirler. Ancak bunlar, AB bünyesinde genel bir çerçeve olmadan ve belli disiplinler temelinde yapılmadan mümkün olmayacaktır. Avrupa Birliği'nin göç konusuna bakışının evrimi her ne kadar son yıllarda Suriyeli göçmenlere karşı olumsuz davranışlar olmuş olsa da, gerçekten dikkat çekicidir ve bu bakış açısının, kurumsal ve yasal anlamda geleceğe taşınması beklenmektedir.

Bu anlamda Avrupa Birliği'nde 1997 yılında Amsterdam anlaşması göç sorununa değinen, insanların serbest dolaşım haklarının prensiplerini ortaya koyan ilk anlaşmadır. Ayrıca göç sorununun ortak bir politika olmasında da ilk adımdır (Apap, 2001: 11). AB'nin genişleme ve ekonomik gelişme süreçlerinde göç sorununun ortak bir politikaya bağlanması çok önemli olmuştur. $\mathrm{Bu}$ anlaşma içerisinde göç ile ilgili düzenlemeler, düzenlemenin Adalet ve Ev İşleri Bölümünde, IV. Başlık olan "vizeler, iltica, göç ve diğer serbest dolaşım hakkı ile ilgili konular" altında bahsedilmiştir. Bu düzenleme, farklı bakış açılarını bir araya getirmektedir ve özel mekanizmanın ulus üstü bakış açısıyla yok olmasını ele almaktadır. Özellikle 1997-2000 arası Avrupa Birliği \%3,5 büyüme kaydetmiştir ve bu büyüme de 2.5 milyon yeni iş olanağının ortaya çıkmasına olanak sağlamıştır. Böyle bir büyüme beraberinde, AB'nin hem daha cazip bir bölge olacağını hem de daha yüksek göç akınlarına uğrayacağını göstermektedir (Silaşi, Rollet, Trandafir ve Vădăsan, 2006: 11).

1999 yılında gerçekleştirilen Tampere programı, göç konusunda Amsterdam anlaşmasından sonra Avrupa Konseyi’nin ortaya koyduğu önemli bir yaklaşımı yansıtmaktadır. Tampere programı, dört başlıklı ortak bir göç politikasını öngörmektedir. Bunlar; Avrupa iltica sistemi, yasal göç ve entegrasyon, AB üyesi olmayan ülkelerin vatandaşları için yasadışı göç ile mücadele ve transit ülkelerle birlikte çalışmayı hedefleyen politikalardır. Bu politikalar, basit de olsa temel yaklaşım getirmesi açısından önemli bir gelişme olmuştur. 2004 yılında Hague Programı, Tampere'de kabul edilenlerin devamı niteliğindedir ve ortak iltica ve göç politikalarını kurumsallaştırmıştır. Sonuç bildirgesinde yer alan 10 maddenin son 2'sinin amacı; göç hareketlerine dengeli bir bakış açısını belirlemek ve göç hareketlerinin pozitif etkisini maksimize etmektir. Hague Programının devamı için 2005 yılında, '3. Dünya ülkesi insanları entegrasyon Ortak Programı' kabul edilmiştir (Collett, 2011).

2005 yılında Avrupa Birliği Komisyonunda Yeşil Doküman içerisinde, göç ile ilgili tüm konuların tartışması yapılmış ve genel bir çerçevede ekonomik göç üzerine bazı belirli kuralların oluşturulması hedeflenmiştir. Bundan 10 yıl sonra, göç konusunun Avrupa Birliği ajandasında önemli bir yer edindiği görülebilmektedir. Yeşil Doküman, üye ülkelerin güncel demografik yapıları ile ilgili sorunları ortaya koymuş ve Avrupa Birliği'nin uluslararası sorumluluklarının altını çizmiştir (Bertozzi, 2007: 11). Bununla beraber Yeşil Doküman, üçüncü dünya ülkeleri vatandaşlarının ekonomik göçleri yanında, Avrupa Birliği vatandaşlarının serbest dolaşım hakkına muhatap olmaları endişesini de taşımaktadır.

$\mathrm{AB}$ ülkelerinin bazıları, göçmen işçilerin ve ailelerinin içinde bulundukları ülkeye adapte olabilmesini sağlamak için birtakım programlar üretmişlerdir. Temel 
Yalova Sosyal Bilimler Dergisi

eğitim, dil eğitimi ve mesleki eğitim gibi hayati öneme sahip olan programlar, işsizlikten en çok etkilenen genç göçmenlere ve özellikle kadınlara yöneliktir (Bingöl, 2006, 79). Bir yönüyle programlar, göçmenlerin hayatın merkezinde olan çalışma hayatına girmelerine yardımcı olmaktadır. $\mathrm{Bu}$ programlar sadece bulundukları ülkede sosyal ve ekonomik içerilmeleri yanında, kendi ülkesine dönenlerin uyumuna da katkı sağlamaktadır.

Eğitim ve öğretim, sosyal anlamda bütünleşmenin vazgeçilmezidir. Dolayısıyla yabancı bir kültürde yaşayan göçmen çocuklarının topluma uyum sağlayabilmesi için iyi bir eğitim görmeleri şarttır. Eğitim, göçmenlerin başarılı sosyo-kültürel entegrasyonları ve sosyal hareketlilikleri için ana önceliktir. Yani göçmen çocuklarının şu anki eğitimsel kazanımları göçmenlerin gelecekteki entegrasyonlarının nasıl gelişeceği konusunda önemli bir göstergedir (Bingöl, 2006: 76).

\section{Avrupa Birliği Göç Politikalarının Sosyal İçermeye Etkisi}

Avrupa birliğinde ortak bir göç politikasının bulunmaması sebebiyle, yerel düzeyde mevcut göç politikalarının incelenmesi bu konunun sosyal içermeyle olan bağını anlamak konusunda yardımcı olacaktır. Bu bağlamda bu bölümde $\mathrm{AB}$ üyesi ülkelerini bir kısmı ayrı ayrı ele alınmıştır.

\section{1. Çek Cumhuriyeti}

Çek Cumhuriyeti'nde göçmenler ekonomik durgunluktan olumsuz şekilde etkilenmiştir. Göçmen halkın işsizlik oranının yerel halktan daha yüksek olma durumu değişmemesine rağmen (\%5.8 yerel ve \%6.8 göçmen, 2009) çek cumhuriyeti durgunluğa karşı önlem olarak, gönüllü geri dönüş programını başlatarak işsiz göçmenlere bir çözüm sunmuştur. 27.700 göçmen bu program kapsamında evlerine geri dönmüştür. Bu program kişilere 500 euro ve ilave olarak uçak biletleri ve bazı giderlerin karşılanmasını kapsamaktaydı (Kristen McCabe, 2009). Bununla beraber göçmenlerin büyük bir çoğunluğu kalmaya devam etmiştir. $\mathrm{Bu}$ durumda İçişleri Bakanlığı belediyeler ile işbirliği içinde acil entegrasyon programına başlamıştır. Öncelikle dil eğitimi, ileri eğitim desteği, sosyal ve hukuki danışmanlık verilmiştir. Buna ek olarak, Çek Cumhuriyeti 14 bölgesinin 10'unda entegrasyon destek merkezleri açmıştır. Çek hükümetine göre Avrupa entegrasyon fonu ve Avrupa sosyal fonu desteğiyle harcanan kaynaklarla, entegrasyon daha önemli ve görünür bir hal almıştır. 2010'da 1 milyon Euro'ya yakın devlet bütçesi İçişleri Bakanlığı ve Çalışma Bakanlığı ve Sosyal İşler Bakanlığı başta olmak üzere eğitim, sağlık, gençlik ve spor, kültür ve bölgesel kalkınma bakanlıkları tarafindan entegrasyon için harcanmıştır (Collett, 2011). 2011 yılında, göçmen politikalarında bazı değişiklikler yapılmıştır. Öncelikle, kamu harcamalarındaki kesintiler entegrasyon bütçesini de etkilemiştir. İkincisi, durgunluk göçmenler için 2011 Şubat ayında gönderilen yeni entegrasyon politikasını da etkilemiştir. Bu politika daha pratik bir yaklaşım içermekteydi ve dil testlerini, 2. Nesil göçmenlerin eğitimlerini, ayrılma öncesi gereklilikleri, tanıtıcı kursları öncelikli olarak değerlendirmekteydi (Collett, 2011). 
Yalova Sosyal Bilimler Dergisi

Çek cumhuriyeti öncelikle göçmen işsizliği ile karşılaştıklarında sorunun bitirilmesi için bazı çözümler ortaya koymuşlardır. Bunlar içinde geri dönüşü özendirme ya da dil ve eğitim kursları önemlidir. Bunun için, Batı Avrupa ülkelerine nazaran Çek Cumhuriyeti'nin ayırdığı pay daha düşük olmasının sebebi, halen göçmen oranının nüfusa göre \%4'ün altında olmasıdır. (Avrupa Birliği ortalaması \%6.4). Sonuç olarak AB'nin kaynak yardımının en önemli rolü yeni politikalar ve girişimler için merkezi destek olmasıdır (entegrasyon destek merkezleri gibi). Bu anlamda, Çek Cumhuriyeti'nin yaptığı tüm faydalı projelerde AB ortak kaynak desteği sunmuştur (Czech Goverment, 2009).

\subsection{Danimarka}

Son dönemde yaşanan ekonomik durgunluk, Danimarka için birçok ülkede olduğu kadar kötü sonuçları doğurmamış ve etkisi kısa süreli olmuştur. Genel makro durum olumlu olmasına rağmen, göçmenlerin ekonomik ve sosyal durumları ortalamanın altında kalmıştır. Zira, göçmenlerin işsizlik oranı \%15 iken yerel halkın işsizlik oranı \%7'dir. Bu oran göçmenlerin aleyhine olmakla beraber 20082010 döneminde yaşanan kriz öncesinde aradaki fark daha azdır. Dolayısıyla son finansal kriz göçmenlerin durumlarını daha da kötüleştirmiştir. Göçmenlerin giderek dışlanmalarının ortaya çıkardığı bu olumsuz durumu azaltmak amacıyla Danimarka'da entegrasyon politikası harcamalarında bu dönemde orta düzeyde bir artış gerçekleştirilmiştir (Liebig, 2007).

Genellikle göçmenlerin entegrasyonunda ekonomik yaklaşım her ülkede olduğu gibi Danimarka'da da benzer önceliği almıştır. Bu anlamda, Danimarka'da Entegrasyon politikası uzun zamandır ekonomik hedefler ile yürütülmesinin sonucunda, firsat eşitliği, eğitim ve çalışma şartları konusunda yereller ile göçmenler arasında fark devam oluşmuştur (Bertozzi, 2007: 9). 2005 yılında yapılan entegrasyon planı sayesinde 25.000 göçmenin iş sahibi olması hedeflenmiştir. Geniş bir sosyal destek mümkün olmakla beraber, entegrasyon politikaları göçmenlerin aktif şekilde entegrasyon planına katılmaları beklentisi üzerine kurulmuştur. Özellikle bu beklenti, dil öğrenimi ve iş bulma konusunda daha da artmaktadır. Entegrasyon politikası Danimarka'da 2008'den beri Göç, Mülteci ve Entegrasyon Bakanlığı tarafından koordine edilmektedir. Bakanlığın bütçesi 2011'de 163.6 milyon Euro'dan 241.4 milyon Euro'ya çıkarılmıştır. Bütçede yapılan bu artışla beraber tanıtım ve dil programları ve göçmenlerin sosyal olarak içerilmelerine yönelik faaliyetlerde de artış sağlanmıştır (Bertozzi, 2007: 9).

Aşırı sağcı ve göçmen karşıtı politika izleyen Danimarka Halk Partisi, Danimarka hükümeti ile 2010 yılında göçmen politikalarını kuvvetlendirme ve bir dizi entegrasyon koşullarının kalıcı ikameti olanlara uygulanması için bir anlaşmaya varmıştır. 2010 yılında aşırı sağ ve göçmen karşıtı olarak bilinen Danimarka Halk Partisi, Danimarka hükümetini uzun süre oturma izni verilen göçmenlere bir dizi entegrasyon koşullarının uygulanmasını ikna etti (Bertozzi, 2007: 9). Bu koşullar, yapılacak testleri, 1 yıl toplumsal aktivitelere katılmayı, yüksek dil yeterliliğine sahip olmayı ve oturma izni başvurusu sonrasında 3 yıl boyunca sosyal desteğe muhtaç olmamayı gerektirmektedir. Hali hazırda çalışmakta olan göçmenler için bu kriterler kolay aş1labilecek olsa da, işsiz durumda bulunan ve gözlemci olarak adlandırdığımız kesim için bu kriterler endişe 
Yalova Sosyal Bilimler Dergisi

vericidir (Bertozzi, 2007: 11). Aslında nüfusu giderek yaşlanan ve artış göstermeyen Danimarka, göçmen kabulüne hazırlanmakta ve bunun için gerekli maddi ve manevi altyapısını da hazırlamaktadır. Ancak, Avrupa'nın birçok ülkesinde olduğu gibi Danimarka'da da göçmenler ve göçmen politikaları göçmen karșıtı așırı sağcılar ile sosyal demokratlar arasında sıkıșmıș durumdadır. $\mathrm{Bu}$ yaklaşım, son yıllarda Suriye'li göçmenlere karşı uygulanan sıkı politikalarda kendini göstermektedir.

\subsection{Almanya}

Almanya entegrasyon politikaları, diğer ülkelerdeki gibi, birkaç bakanlık tarafindan yürütülmektedir. Bunlar; Federal Eğitim ve Araştırma Bakanlığı, Sosyal hizmetler ve Çalışma Bakanlığı, Aile Bakanlığı, Kadın ve Genç Bakanlığı gibi bakanlıklardır. Bu bakanlıkları organize eden ise ana koordinatör olan Federal Göçmen ve Mülteci Bürosu'dur (BAMF). BAMF ülke genelinde eğitim ve iş odaklı olarak entegrasyon politikalarını yürütmekle sorumludur. $\mathrm{Bu}$ nedenle entegrasyon kurslarını ve geniş çerçevede entegrasyon projelerini ülke çapında desteklemektedir. Öte yandan, bölgesel olarak belirli alanlardan sorumlu olan 'Lander' yönetimleri de bazı entegrasyon politikalarının yürütmesini sürdürmektedir (Tuncer, 2012: 799).

“Alman Yabancılar Politikası"nı belirleyen düşünce, ya işçi sıfatıyla Almanya'ya gelenlerin geri döneceği, ya da Almanya'yı yaşama alanı olarak seçen yabancıların hâkim toplumun ve kültürün mesleki, sosyal ve kültürel standartlarına benzeşeceği ve böylelikle hâkim toplum ve sonradan ona dâhil olan grup arasındaki farkın nesiller itibariyle azalacağı temeli üzerine kurulmuştur. Başka bir ifadeyle "Alman Yabanc1lar Politikası"nda etkin olan entegrasyon ya da uyum anlayışı sonucunda farklı kültüre mensup insanlar, hakim kültür içinde erimeleri beklenmektedir (Bingöl, 2006: 53).

Alman göç ve entegrasyon stratejisi çok yakın bir zamana kadar Alman toplumunun sözde-homojenliğini korumaya dayanmıştır. Alman göç politikası dört unsura dayanmaktadır (Bingöl, 2006: 53).

- Etnisite

- Alman olmayanların kalıcı göçmenliğinin reddi

- Avrupa Birliğine entegrasyon

- İş piyasasının koşullarına göç önlemlerini ayarlama

Almanya, göçmenlerin yeni kültürü kabul etmek konusunda cesaretlendirilmesi gerektiğine karar verdiğinden, 2005 yllında entegrasyon anlayışı değişime uğramıştır. Yeni gelenler için 600 saatlik dil eğitimi, dilde akıcılık kazandırılması amacıyla uygulamaya başlanıldı. Yeni entegrasyon paketinde bu ve buna benzer kurslar ile Alman kültürü, vatandaşlık hak ve ödevleri ile bölgesel adetler, ulusal önemli tarihler ve Alman demokratik sistemi aktarılmaya çalışılmaktadır. Dolayısıyla, Almanya'ya gelecek olanlara izin vermeden önce, zaten gelmiş olanların entegrasyonuyla ilgilenmenin daha mantıklı olduğu düşünülmüştür (Snyder, 2006: 24). 
Yalova Sosyal Bilimler Dergisi

Alman olmayan göçmen nüfus giderek yerleştikçe onların vatandaşlığa geçme oranlarındaki düşüklük gittikçe sorunlu, vatandaşlık statüleri de -özellikle Doğu Avrupa'dan gelen etnik Alman göçmenlere verilen otomatik vatandaşlığın karşısında- yadırgatıcı bir hal almıştır (Ertan, 2007,107-110). Alman olmayanlar, geçici yerleşenler veya yabancılar sayıliyordu ve onları entegre etmek için, yerleşmeyi kalıcı olarak planlasalar dahi, gereken çaba sarf edilmiyordu. Vatandaşlığa geçen Alman olmayan kişilere bir yemin imzalatıliyor ve Alman hukukuna ve liberal demokratik yapıya uyacaklarına dair söz/yemin alınıyordu. Ayrıca, diğer vatandaşlığından da vazgeçmesi isteniyordu (Karakuş, 2007: 33).

2008 Ekonomik krizi dünyanın gelişmiş ülkelerini oldukça sarmış olmasına rağmen, Almanya'yı ise diğer Avrupa ülkelerine göre fazla etkilemediği görülmüştür. İçişleri bakanlığı bütçesi 2011 y1lında genel olarak \%2 düşüşle 5.402 milyar Euro'dan 5.312 milyar Euro'ya inmiştir. Ancak BAMF'ın 218 milyon Euro olan entegrasyon bütçesi, bu kesintilerin dışında tutulmuştur (Collett, 2011). Sanayi üretimi odaklı olan ekonomisi sayesinde Almanya büyümeye devam etmiş ve sosyal harcamalarını da kısıtlamamıştır. Bu anlamda, 2010 yılında göçmenlerin entegrasyonunun nasıl kuvvetlendirileceği tartışmaları yapılırken, devlet göçmenlerin entegrasyonu ile ilgili öncelikli harcamalarını kısıtlamamıştır. Almanya bu dönemde dil yeteneğinin geliştirilmesi, eğitim, ekonomik sektörlere girişin kolaylaşması gibi konulara öncelik vermiş ve bunlara ek olarak da diyalog ve suçtan arındırma ile ilgili sosyal içerme politikalarına da devam etmiştir (Collett, 2011).

AB'nin en büyük ekonomisine sahip olan Almanya son yıllarda almış olduğu aşırı göçler nedeniyle sıkıntılar yaşamaktadır. Göçmenlere karşı daha 1lımlı yaklaşımlar sergileyen Almanya ve İsveç, Avrupa'ya göç eden ve büyük çoğunluğu Suriyeli olan göçmenler için politikalar üretmeye gayret etmektedirler. Her ne kadar bu politikalar ulusal olsa da, Almanya ve İsveç için önemli olan bu politikaların Avrupa Birliği'nin yaklaşımı olması ve diğer ülkelerce de benimsenmesidir (The Economist, 2016). Böylece göçmen krizinin yönetimi daha bütüncül olacak ve hem göçmenler hem de ülkeler açısından kolay olacaktır.

\section{4. İrlanda}

İrlanda küresel mali krizden ve ekonomik durgunluktan en şiddetli etkilenen ülkelerden birisidir. $\mathrm{Bu}$ nedenle 2010 yılında iflas1 ve Avrupa Birliği'nden ayrılması gündeme gelmiştir. Hem yerel halkın hem de göçmenlerin işsizlik oranları ikiye katlanmıştır. Hükümetin asgari ücreti 7.65 Euro'ya düşürmesi birçok vasıfsız göçmen işçiyi zor durumda bırakmıştır. Kayıtlı göçmen işçi sayısı 2008 'de 156.151 iken 2010 yılında 69.038'e düşmüştür. İrlanda'ya göç hareketleri son yıllarda başlamış bu nedenle hızlı bir şekilde göçmen ülkesi konumuna gelmiştir. İrlanda hükümeti 2007 yılında göçmenlere entegrasyon politikaları uygulamaya başlamıştır. Hükümet entegrasyon politikalarından sorumlu bir devlet bakanlığı oluşturmuştur ve bu bakanlığa 9.3 milyon Euro aktarılmıştır (Collett, 2011).

May1s 2008'de İrlanda hükümeti 'Göçmen Topluluğu: Entegrasyon Stratejisi ve Çeşitlilik Yönetimi" adı altında yeni bir strateji belgesi yayınlamıştır. Ancak bundan bir süre sonra 2008 finansal ekonomik kriz ortaya çıkmıştır. Kriz 
şartlarında bu belgenin ön gördüğ̈̈ yaptırımları uygulamak mümkün olamamıştır. Kriz ile birlikte bakanlığın bütçesi de kesintiye uğramış ve 2011 yılında bütçesi 4.1 milyon Euro'ya düşmüştür. 2010 yılında eğitim departmanının ikinci dil olarak İngilizce öğretmek için harcadığı kaynak 120 milyon Euro'dan 98 milyon Euro'ya indirilmiștir. Bunun yanında 500.000 Euro bütçesi olan ulusal ırkçılık ve çok kültürlülük danışma komitesi kaldırılmıştır. Eşitlik Otoritesi bütçesinin \%43’ünü kaybetmiştir. Bu kesintiler eğitim ve yetiştirme faaliyetlerinin de aksamasına sebep olmuştur (Crowley, 2010). Göçmen politikaları konusunda tek olumlu gelişme Göçmen Topluluklara İş Kazandırılması Programı (EPIC) bütçesi, 276.700 Euro'dan 512.568 Euro'ya yükseltilmiş ve program ile göçmenlerin iş bulması ve iş eğitimleri alması hedeflenmiştir.

Bütçedeki sıkıntılara rağmen, İrlanda Hükümeti göçmenlerin entegrasyonuna odaklanmaya devam etmiştir. Göçmenlerden oluşan Göçmen Başkanlık Konseyi ile birlikte 2010 yılında kültürler arası bir eğitim stratejisi için çalışmalar yapılmıştır. Eş zamanlı olarak, hükümet işsiz göçmenlerin desteklenmesi için bazı önlemler almıştır. 2009 yılında 'grace' süreci ile çalışma izni bitmek üzere olan işsizlerin izinleri 3 aydan 6 aya uzatılarak tekrar başvuramayacak olan işsizler için bir yol açılmıştır (Collett, 2011).

Özellikle kriz nedeniyle İrlanda'nın yaşadığı bütçe sıkıntısı sadece kamuda etkisini göstermemiş, ayrıca sivil toplum örgütlerinin de bu dönemde kaynak sıkıntısı nedeniyle çalışmalarında yavaşlama olduğu görülmüştür. Bunların dışında diğer politika değişiklikleri göçmenlerin entegrasyonunu destekleyecek şekilde, eğitim, iş hayatı gibi konularda ve politika yapma süreçlerine dahil edilmeleri ile göçmenlerin sosyal olarak içerilmelerine katkı sağlamak için kayda değer çalışmalar yapilmıştır.

\subsection{Hollanda}

Hollanda'nın 1980 sonrası dönemde göçmenlere yönelik politikaları 3 ayrı dönemde incelenebilir. Bunlar; 1980'lerin başından 1989'a kadar çok kültürlülük dönemi, 1990'lardan 2000'e kadar entegrasyon dönemi ve 2000'lerle başlayan yeni entegrasyon ya da entegrasyonun asimilasyoncu tarza geçiş dönemi olarak sınıflandırılabilir. Bu süreçte göçmenlere yönelik yaklaşım ve politikalarda geçişler olduğu gibi her on yılda yeni bir isimlendirmenin tercih edildiği de gözlenmektedir. Hollanda'da Hollanda kökenli olmayanlar, 1980'lerde sosyo-ekonomik, sosyokültürel ve yasal açıdan konumları düzeltilmesi gereken "etnik azınlıklar"dır. 2000 'lerde ise bu grup, medeniyetler çatışması ile ulusal kimlik kapsamında, sosyal kaynaşma önünde engel ya da tehdit olan -özellikle Müslüman olanlar"göçmenler" olarak kategorize edilmiştir. Kısaca Hollanda'nın "öteki"ne yaklaşımında söylemsel değişiklikler olsa da temelde süreklilik vardır (Köse, 2012: 40).

Ülkelerinde yaşayan yabancıların kendi toplumsal şartlarına uyum sağlamaları konusunda farklı entegrasyon politikaları ileri sürülmekle beraber, Hollanda yetkilileri "kendi kültürel kimliğini koruyarak entegrasyon" fikrini benimsemektedir ve bu husus 1983 tarihli Azınlıklar Bildirgesinde de yer almaktadır (Bingöl, 2006: 54). Dolayısıyla Hollanda diğer AB ülkelerine nazaran 
Yalova Sosyal Bilimler Dergisi

göçmenleri tek kültürlü yaşama yönlendirme yerine, çok kültürlülüğü tercih etmiştir.

Hollanda'daki çok kültürlülük tartışmaları, kültürel "öteki" ile muhatap olmanın ve bu "öteki" ile tanımlanmıș kümelerin, sisteme meșru hukuki zeminde eklemlenmelerinin yöntemleri üzerinedir. Hollanda'ya göçmen olarak gelenler, Hollanda toplumunun kurucu unsuru olarak algılanmamışlardır. $\mathrm{Bu}$ sebeple Hollanda kendi kimliğini ya da "hayali toplumunu" yeniden şekillendirirken, kültürel "öteki"nin de farklılığını ve "öteki"liğini vurgulayarak sistemle bağını oluşturmaktadır (Köse, 2012: 39). Ocak 1994'te parlamentoya sunulan öneride göç politikalarının etkinleştirilmesine ilişkin üç temel yoldan bahsedilmiştir. Bunlar (Bingöl, 2006: 55);

- Daha sıkı giriş kontrolleri,

- Kaçak çalışanlara yönelik sıkı tedbirlerin alınması,

- Daha etkili sınır dış1 etme prosedürlerinin geliştirilmesidir

Göçmenlerin varılan ülkenin yaşayış tarzının ve değerlerinin kabul edilmesinin talebinin neticesi olan göçmenlik testleri Hollanda'da yapılmaktadır. Diğer ülkelerin aksine Hollanda'nın sınavı, göçmen ülkeye varmadan önce yapılmakta, göçmenin ülke ile ilgili kültürünü, günlük hayatını, tarihi ve politik yapısını bilmesini gerektirmektedir. Hollanda'da ve Almanya'da olduğu gibi Müslüman kimliği, kadına karşı toleranssız ve saldırgan olarak kabul edildiği için, sinavlarda bu gibi karakteristik özelliklerin yeni ülkede kesinlikle kabul edilmeyeceği zorla gösterilmektedir (Snyder, 2006, 49). Almanya ve Hollanda'da vatandaşlık entegrasyon sınavları, Müslümanlar açısından İngiltere'den daha önyargılı içerik söz konusudur.

Hollanda'da göçmenlere yönelik politikanın hedeflerindeki ve odağındaki değişim, 1994'teki yeni bir belge olan Etnik Azınlıkların Entegrasyon Politikası Memorandumu'nda görülmüştür. Entegrasyon Politikası'nın temeli sayılabilecek bu belge, mevcut söylemi cumhuriyetçi bir yapıda ve göçmenlerin iyi vatandaşlığına odaklanarak yenilemiştir. Ancak bu rapor entegrasyonun grup boyutuna vurgu yapmamaktadır. Yeni anlayış, göçmenlerin hükümet imkanlarına dayanması yerine bağımsızlığını vurgulamaktadır. Artık göçmenlerin yerleşim, eğitim ve istihdam yönüyle sosyo-ekonomik alanda eşit katılımını desteklemek ve yeni gelenlerin öncelikli entegrasyonunu kolaylaştırmak, kursların temel hedefi olmuştur. Bu doğrultuda Hollandaca, topluma intibak ve mesleki eğitim kursları geliştirilmiştir (Köse, 2012, 55).

Ekonomik krizle beraber diğer gelişmiş ülkelerde olduğu gibi Hollanda'da da bütçe kesintileri olmuştur. 2010 yılının ortasında aşırı sağ PVV partisinin gayri resmi olarak koalisyonda yer almasi hem entegrasyon politikalarına harcanan bütçenin kısıtlanmasına hem de politikaların tavrının değişmesine yol açmıştır. Gayri resmi olarak kurulan koalisyonun da etkisiyle, zaten sert olan göç ve entegrasyon politikaları daha da netleşmiştir. Göçmenlerin belli kıyafetler giymeleri yasaklanmış ve güvenlik adına bazı özgürlükler zedelenmiştir. Bu anlamda, Burka (yüzü kapatan örtü) giyilmesine yasak gelmiş ve daha fazla göç gelmesini engelleyici politikalar geliştirilmeye çalışılmıştır. Göçmenlerin entegrasyonunu sağlayan bütçede önemli kesintiler yapılmıştır. Entegrasyon 
Yalova Sosyal Bilimler Dergisi

programını ve bunun için belediyelerin finansmanını koordine eden Barınma, Toplum ve Entegrasyon Bakanlığı, batılı olmayan göçmenlerin entegrasyonu için kullandığı bütçesini, 2015 y1lında 501 milyon Euro'dan 111 milyon Euro'ya düşürerek, 2010'a göre \%80 oranında azaltmıştır (Collett, 2011).

Sivil entegrasyon fonu, dil ve oryantasyon kurslar1, 2010'da 439.7 milyon Euro'dan 2015'de 44.6 milyon Euro'ya inmiştir. Bu bütçe bir süredir ülkede yaşayan göçmenlere aktarılmış ve göçmenlerin birçoğu bu kurslardan yararlanmıştır. Şu anda ise bu fonları göçmenler kendileri karşılamaktadır. Bu fonlara ödeme yapabilmeleri için göçmenlere bir kredi sistemi oluşturulmuştur. $\mathrm{Bu}$ durumun ne kadar sürdürülebilir olduğu tartışmalıdır. Hem göçmenlerin fona katkısının alınmasının sakıncası hem de kamunun ayırdığı bütçe kesintileri sonucunda, ne kadar kaliteli eğitim verilebileceği de ayrı bir tartışma konusudur.

Eyaletlerin de göçmenler gibi entegrasyon harcamalarını kendilerinin üstlenmesi, hükümet tarafından istenmektedir. Eyaletlerde entegrasyon genel eğitim, sağlık ve diğer sosyal politikalarla beraber yürütülmektedir. Sivil toplum örgütlerinin finansal kaynak talepleri de çok gerçekçi ve ileri seviyede faydalı projeler olmadikları takdirde reddedilmektedir (Collett, 2011).

Genelde entegrasyon programı kesintileri, ülkenin genel ekonomik sıkıntılarından çok fazla etkilenmiş olduğu görülmektedir. Bununla beraber, aşırı milliyetçi söylemlerin artması, politik endişeleri de gitgide artırmakta ve böylece göçmenler yerel halktan zaman içerisinde ayrışmış olmaktadır. Hollanda'nın göçmen politikaları, pratikten uzak ve göçmenlerin kendi kendilerine yardım etmeleri felsefesi ile kurulmuş bir sistemdir. Belki göçmenlerin kendi programlarını desteklemesi kulağa hoş gelebilir fakat bunun pratikte hiçbir sorunu çözmeye yaramadığı görülmektedir (Collett, 2011).

\subsection{Portekiz}

Kriz döneminde kamu harcamalarında kesintilere gidilmesine rağmen, Portekiz hükümeti göçmenler ile ilgili politikalarını kararlı bir şekilde sürdürmeye devam etmiştir. Yönetime ayrılan bütçe baskı altında olmasına rağmen, hükümet ekonomik durgunluğun etkilerini azaltmak için göçmenlerin iş bulmalarına yardımcı olmuştur.

Portekiz'de göçmenler ve onların entegrasyonu konusunda hükümetin birçok farklı birimleri görevlidir. Kültürlerarası diyalog ve entegrasyon yüksek komitesi (ACIDI) 2007 yılından beri göçmenlerin entegrasyonunu koordine eden merkezdir. ACIDI bünyesinde bulunan Ulusal Entegrasyon Destek Merkezi (CNAI), barınma hizmetlerinden, gerekli niteliklerin tanımlamasına kadar tüm bakanlık ve kurumlarca yapılan barınma hizmetlerinin koordinasyonundan sorumludur. Ayrıca, Çalışma ve Sosyal Güvenlik Bakanlığı ve Eğitim Bakanlığı'nın ortak girişimleri ile 11.4 milyon Euro bütçe ile yapılan "Herkes için Portekizce" dil programı da göçmenlere yönelik önemli bir entegrasyona katkı sağlamıştır.

K1sa sürede Kültürlerarası Diyalog ve Entegrasyon Yüksek Komitesi ACIDI'nin bütçesi 2007'de 6 milyon Euro'dan 2009` da 13.5 milyon Euro'ya 
Yalova Sosyal Bilimler Dergisi

ulaşmıştır. Entegrasyon politikalarının önemine binaen bu artış milli gelir artışının çok üstünde bir artıştır. Avrupa Birliği bağışları bu miktarın \%40‘'nı oluşturmaktadır. 2010 yılında bu bütçe biraz azalmış ve 12.1 milyon Euro'ya inmiş ve Avrupa Birliği katkısı yarı yarıya olacak duruma gelmiştir. ACIDI bütçesinin neredeyse yarısını, direkt olarak göçmenlere ya da bu konuda çalışan sivil toplum örgütlerine aktarmıştır (European Commission, 2010).

2011 için Portekiz hükümeti ACIDI'nin bütçesini \%4.7 artırmıştır ve Lisbon'da CNAI için ayrı bir bina yaptırmıştır. Hiçbir entegrasyon projesi kesintiye uğramamıştır. Göçmenlerin Entegrasyonu için ikinci plan Ağustos 2011 'de yürürlüğe girmiş̧ir. Bu anlamda, 90 farklı konuda yeni projeler aktif olmuştur (Acidi, 2010). Bu projeler, özellikle göçmen vatandaşlardan sosyoekonomik kırılganlık içinde olanları desteklemeye yöneliktir.

- Göçmenlerin temel literatür eğitimine tabi tutularak sosyal kazanımlarını artırmak

- Göçmen girişimci ve kılavuzluk eğitimleri ve yeni bir iş kurmak için destek olma süreçlerinin geliştirilmesi

- $\quad$ Aşırı fakirlik ve muhtaçlık durumu çeken göçmenlere sosyal destek ve yardımların yapılması

Diğer göçmen sorunları; ailelerin birleşmesinde kolaylık sağlanması (evlilik süreçleri), işsiz kalmış göçmenlerin oturma izinlerinin uzatılması gibi, konularda da önlemler alınmıştır.

\section{7. İspanya}

İspanya gerek Latin Amerika ülkelerinin krizde olmasından dolayı gelen gerekse Kuzey Afrika'dan tarım sektöründe çalışmak amacıyla gelen göçmenler nedeniyle önemli bir göçmen ülkesi olmuştur. İspanya, Almanya, İtalya ve Yunanistan gibi Avrupa Birliği'nde göçmenlerin giriş yaptığı önemli bir ülkedir. Arjantin'deki ekonomik krizden ve Arjantin'de İspanya şirketlerinin etkinliği ve dil ve kültür gibi nedenlerden dolayı Arjantin'den İspanya'ya göç akışı olmuştur. Ayrıca birçok Avrupa ülkesinin Kuzey Afrika ülkelerini uzun süreler yönetmeleri nedeniyle, Kuzey Afrikalıların İspanya üzerinden Avrupa'ya göçleri söz konusu olmuştur. Dolayısıyla İspanya, Avrupa Birliği içerisinde göç politikalarının oluşmasında önemli bir aktör olmaktadır.

İspanya halkının Kuzey Afrika'dan gelen Müslüman olan göçmenlerin terör bağlantıları olabileceğine dair önyargılı düşünce, tutum ve davranışları, göçmenlere karşı güvenlik politikalarının öne çıkmasına neden olmaktadır. Hatta halkın \%51'i suç ve göçmenler arasında yakın bir ilişki kurmaktadır (Ertem, 2007: 145).

Ekonomik krizin etkilerinin İspanya'da çok sert geçmesi dolayısıyla, göçmen akışında, işsizliğinde, ve kaçınılmaz olarak, entegrasyon harcamalarında olumsuz gelişmeler olmuştur. Bununla birlikte, hükümet, 1rkçılıkla mücadele, yabancı düşmanlığı gibi daha genel konulara yatırıma da yönelmiştir.

Özellikle göçmen nüfus ekonomik durgunluk süresince önemli sıkıntılara maruz kalmış ve daralan ekonomiden olumsuz etkilenmiştir. Yerel İspanyol halkta 
Yalova Sosyal Bilimler Dergisi

\%18'e yükselen işsizlik, göçmenlerde \%30'lara kadar gelmiştir. Ekonomik sorunlar, işsizlik artışı, genel talebin azalması, İspanya'ya yeni gelen insan sayısını da azaltmıştır. Entegrasyon politikaları Çalışma ve Göç Bakanlığı tarafindan koordine edilmekle beraber, göç ve göçmen konuları geniş bir çerçevede birçok devlet organı tarafindan ve bölgesel belediyeler ve otonom topluluklar tarafindan yürütülmektedir. İspanya hükümeti Madrid gibi otonom toplulukları desteklemektedir ve bu amaçla 2009 yllında Madrid'e 200 milyon Euro fon ayırmıştır. Ancak bu yardım önce 100 milyon Euro'ya düşürülmüş ve 2011'de ise 70 milyon Euro'ya indirilmiştir (Davis, 2008). Bölgesel topluluklar entegrasyon politikalarını yönetmekte ve bu politikalara kendi bütçelerinden destek olmaktadırlar. Yeni fonlama çerçevesinde hükümet ile topluluklar arasında sağlık ve eğitim harcamaları bu kesintilerin dışında tutulmuş ve böylece harcamalar artış göstermiştir. İlave edilen ek kriterler sayesinde tahsis edilen bütçe artırılmaktadır. Nüfus yoğunluğu ve İspanyolca dil sorunları fazla olan yerlere yani, yoğun göçmen nüfusun yaşadığı yerlere daha yüksek destek sağlanmaktadır (Collett, 2011).

2011-2014 arasında Çalışma ve Göç Bakanlığı Vatandaşlık ve Entegrasyon için İkinci Stratejik Plan'1 uygulamaya ve geliştirmeye çalışmışır. Resepsiyon politikalarını bırakıp, daha ileri seviyede entegrasyonu sağlayan eğitim ve iş sağlama politikalarına yönelmiştir. Buna ek olarak stratejik plan ile yüksek göçmen nüfusa sahip mahalle ve bölgelerin toplum/halk bilinci geliştirmesi hedeflenmiş ve 1rkçılık ve yabancı karşıtlığı ile mücadele edilmesi hedeflenmiştir. Bu politikalar İspanya'nın uzun dönemli entegrasyon politikalarında ki değişimi göstermektedir. Entegrasyon fonları geçen yıllarda düşse de, genel çalışmaların da katkısıyla bu eksikliğin etkisi azaltılmaya çalışılmaktadır.

\section{8. İsveç}

Global krizin etkisiyle yavaşlayan İsveç ekonomisi 2009'da gerçekleştirilen genel seçimler sonrasında kendini toparlayabilmiştir. İsveç daha önceden geliştirdiği entegrasyon projelerine devam edebilmiş ve daha fazla yatırım yaparak yeni gelen göçmenlerin iş sahibi olmasına odaklanmıştır. Genel olarak 2010'da ülke ekonomisi toparlanmışsa da yerel halk ve göçmenler arasında ki işsizlik oranı fark1 çok yüksek olmuştur (yerel halk: \%8, göçmenler \%19.2). Önceden daha az olan bu fark kriz döneminde mevcut yüksek seviyeye ulaşmıştır. İsveç hükümeti için kriz döneminde bütçe kesintileri yapmak yerine açılan bu farkı kapatmak öncelik olmuştur.

2010 seçimlerinde hükümet değişmese de azınlık hükümeti durumundadır. Aşırı sağ İsveç Demokrat Partisi meclisteki çoğunluk sandalyesini kazanmasına rağmen, halkın göçmenlere bakış açısı nispeten daha yumuşaktır. Fakat her geçen gün bazı gruplar daha da sertleşmektedir. Uppsala Üniversitesi'nin yapmış olduğu yıllık çalışma bunu doğrulamaktadır (Sweden, 2010).

Entegrasyon ve Cinsiyet Eşitliği Bakanlığı, entegrasyon politikalarının koordinasyonunu 2011 y1lına kadar sürdürmüştür. İsveç hükümeti bu görevi Çalışma Bakanlığı'na verme kararı almış ve entegrasyon ve göç konusunun çalışma hayatı ile daha da sıkı bir şekilde bağlantılı çalışmasını sağlanması amaç edinilmiştir. 2010 aralık ayında Tanıtma Yasası geçmiş ve İsveç Kamu İstihdam 
Yalova Sosyal Bilimler Dergisi

Kurumu'nun hizmetlerine güçlü bir sorumluluk verilerek, yeni göçmenlerin insanca karşılanması ve özellikle tanıtım planlamalarının geliştirilmesi, sivil oryantasyonun sağlanması, dil kurslarının verilmesi ve çalışma hayatına girişlerine hazırlanmasında gerekli şartların yerine getirilmesi hedeflenmiştir. Entegrasyonu güçlendirecek olan bu yasa tamamen işlevselleştiği zaman hükümetin göçmenler için yaptığı entegrasyon harcamaları 900 milyon İsveç Kronu'na ulaşacaktır. 900 milyon İsveç Kronu yaklaşık 103 milyon Euro olmaktadır ve bu rakam 2010 yılına göre \%15'lik bir artış anlamına gelmektedir (Sweden, 2010).

İsveç'te tanıtım kursları sadece sosyal yardım parası alan göçmenlere zorunludur. Yeni gelen göçmenlerden en az 16 yaşında olanlar bu programa girmeye hak kazanırlar. Yine diğer programlara benzer şekilde dil eğitimi, sosyal hayatı ve günlük yaşamı tanıma ve İsveç toplumunu ve iş hayatını anlamaya yönelik hizmetler verilmektedir (Tekin, 2009, 91). Çalışma hayatına geçiş de, İsveç hükümeti dil yetkinliğinin artırılması için politikalarını gözden geçirmekte ve göçmen çocuklarının eğitimlerini artırabilmek için daha detaylı olan önlemler almaya, komşuluk ilişkilerini ve vatandaşlık değerlerini yükseltmeye çalışmaktadır. İsveç Demokrat Partisi'nin zaferi bir duraksamaya neden olsa da İsveç entegrasyon politikalarına hızlı bir şekilde devam etmekte ve kriz etkisine rağmen uygulamada başarılı bir görüntü ortaya koymaktadır.

\section{9. İngiltere}

İngiliz hükümeti, göçmenlere yönelik harcamalarda ekonomik durgunluk ve kamu borçlarının yığılması nedeniyle önemli kesintilere gitmiştir. $\mathrm{Bu}$ da entegrasyon programının yavaşlamasına ve toplum desteğinden uzaklaşmasına neden olmuştur. Bu durum göçmenlerin entegrasyonu konusunda politik felsefenin ve önceliklerin değişmesine yol açmıştır. İngiltere'de genel işsizlik oranı 7.8 iken göçmenlerde bu oran 9.2 olarak gerçekleşmiştir (Collett, 2011).

İngiltere'nin entegrasyon bütçesi analiz edildiğinde 2008 krizi dönemi ile ilgili bu harcamaları tam olarak tespit edebilmek mümkün değildir. Buna ek olarak net bütüncül bir entegrasyon politikasından da söz etmek zor olacaktır. 2006 yılında entegrasyon politikalarında sorumluluk, Başbakanlıktan yeni oluşturulan Topluluklar ve Yerel Yönetimler Departmanı'na resmi olarak devredilmiştir (Somerville, 2007). Bununla beraber göçmen grupların entegrasyonu ile ilgili konular çeşitli hükümet kanallarından maddi olarak beslenmektedir. Bu çoklu yapı geniş bir politika çerçevesi ve göçmen entegrasyonu konusunda farklı eğilimlerden kaynaklanmaktadır. Bu anlamda, sosyal kaynaşma ve refah politikaları, daha geniş anlamda insan hakları ile eşitlik ve daha çok mülteci entegrasyonuna evrilmiştir.

Ayrıca gömenlerin belli testlerden geçmesi uyumlarını artırmak açısından önemli görülmüştür. Ancak, İngiltere'deki sinavlar bir kimlik oluşturmaz veya belirli bir grubu hedef almaz. Bunun yerine vatandaşlık bilgisi ve kültürel bilgiler vermeye odaklanır. İngiltere'de de entegrasyon sınavı ile vatandaşlık hakkı verilmektedir. "Life in the United Kingdom" sınavını geçmek ya da İngiliz dili ve vatandaşlığı derslerine katılıp geçmek gerekmektedir. Sınav, vatandaşlığa geçiş ve entegrasyon için bir yöntem olarak görülmektedir. Kursların ve sınavların amacı herkesin İngiliz değerlerine aşina olmasını sağlamaktır (Snyder, 2006, 49). Sınav, 
Yalova Sosyal Bilimler Dergisi

göçmeni yeni yaşamına entegre etmek için kullanılmaktadır. İngiltere yeni vatandaş olanların bir törenle yemin etmelerini ve kurallara uyacaklarını, değerleri izleyeceklerini vb. taahhüt etmelerini istemektedir. Kişinin İngiliz haklarına ve özgürlüklerine sayg1 duyacağı da eklenmiştir (Snyder, 2006, 45). Hollanda gibi İngiltere'de de çok kültürlü çoğulcu vatandaşlık rejimi vardır. Azınlıkların çoğu İngilizlerle tam eşit, sosyal ve politik haklara sahiplerdir. Fakat kültürlerini de kaybetmezler. Beş yıl Birleşik Krallık'ta yaşadıktan sonra toprakla gelen hakları kazanırlar. Birkaç nokta da entegrasyon fonlarında ki değişiklikler tespit söz konusudur (Peutrell, 2010).

- Topluluklar ve Yerel Yönetimler Departmanı (CLG) 2010 yılında 1.116 milyon Sterlin değerinde bütçe ile çalışırken, 2014-15 yılında rakam yarıya inmiştir. $\mathrm{Bu}$ durum birçok sosyal içerme ve toplumsallaşma projelerinin iptaline yol açmıştır. 'Connecting Communities' gibi önemli entegrasyon politikalarının ana öğelerinden biri olan proje buna örnektir. Hükümet verilerine göre kaynaklar daha çok anti- radikalleşme çalışmalarına yönelmiştir.

- CLG'nin göçmen fonu, göçmenlerin vize ücretlerinden elde edilen bir gelir olmakla beraber, gelen 50 milyon sterlin bütçe kaynağı kaldırılmıştır. $\mathrm{Bu}$ gelir hükümet dışı ve yerel hükümetlere bağlı göçmenlerin toplum üzerinde yarattığı etkiyi azaltmaya yönelik çalışmalarda kullanılmaktaydı. 2010 yılı hükümet harcamaları incelendiğinde, bu kaynak ülkenin sınırlarını daha iyi koruması, kontrollü mülteci ve göçmen kabulü ile ülkeye gelir ve fayda sağlayacak göçmenleri çekebilmek için kullanıldığı anlaşılmaktadır (HM Treasury, 2010).

- Başka Dil Konuşanlar İçin İngilizce (ESOL) programı bütçe kesintileri ve kısitlamalar ile mücadele ederken, 2011'den beri geçerliliği sorgulanmaktadır. 4.5 milyon sterlin Öğrenen Desteği Fonu tamamen kaldırılınca, düşük gelirli göçmenlere kurs ücretlerinde yardım etmek zorlaşmıştır. $\mathrm{Bu}$ durum göçmenlerin kendi dil eğitimlerini karşılamaları gereksinimini doğurmuştur (Peutrell, 2010).

- Göçmenler üzerinde çalışan sivil toplum örgütleri de kesintilerden payını almıştır. Örneğin Mülteci entegrasyon destek hizmetleri büyük baskı altındadır. Mülteci Konseyi, devlet desteğinin 2011'de \%62 azaldığını ifade etmiştir. Mülteci entegrasyonu ve istihdam hizmetleri 2011 Eylül ayından itibaren durmuştur (Peutrell, 2010).

\section{Sonuç}

Avrupa Birliği sosyal politikalar konusunda olduğu gibi göç ve göçmenler konusunda da yeknesaklığa sahip değildir. Birliğe üye olan ülkelerin ekonomik ve sosyal durumları aynı olmadığı için sosyal politikalar ve göçmenlere dair düzenlemeler serbest bırakılmıştır. Dolayısıyla, her ülkenin yasal ve kurumsal mevzuatı farklılıklar arz etmektedir. Bu farklılıklara rağmen özellikle göçmen politikaları konusunda Avrupa Birliği kapsamında görüşmeler söz konusu olmaktadır. Hatta son yıllarda AB ülkelerine doğru başta Suriyelilerin fazla sayıda göç etmeleri birliği zor durumda bırakmıştır. Hatta Schengen vize sistemi 
durdurulmuş, güvenlik kaygısı öne çıkmış ve entegrasyon politikaları olumsuz bir yöne doğru evrilmeye başlamıştır.

Son yıllardaki aşırı göç, AB'nin siyasi yapısını tehdit etmeye neden olacak değișimleri tetiklemektedir. Așırı göç ve mevcut göçmenler, AB içerisinde yabancı düşmanlığını (xenophobia) tetiklemekte ve Doğu Avrupa'dan başlayarak radikal sağ partilerin yüksek oy oranlarına sahip olmalarına yol açmaktadır. Radikal sağın Doğu Avrupa'dan Batı Avrupa'ya doğru yayılması ise AB içerisinde belirsizliklerin ve beraberinde korkuların artmasına yol açacaktır.

Göçmenlere karşı daha 1lımlı yaklaşımlar sergileyen Almanya ve İsveç, Avrupa'ya göç eden ve büyük çoğunluğu Suriyeli olan göçmenler için politikalar üretmeye gayret etmektedirler. Her ne kadar bu politikalar ulusal olsa da, önemli olan bu politikaların Avrupa Birliği'nin yaklaşımı olması ve diğer ülkelerce de benimsenmesidir. Böylece göçmen krizinin yönetimi daha bütüncül olacak ve hem göçmenler hem de ülkeler açısından kolay olacaktır.

Avrupa Birliği’nde net ortak bir göç politikasının bulunmaması, bu alanda geliştirilen politikaların ve uygulamaların doğal olarak, ekonomik, siyasal ve toplumsal gelişmelere bağlı sürekli değişmesine sebebiyet vermektedir. Üye sayısı giderek artan ve bununla birlikte sürekli yenilenen yapıya sahip olmasından dolayı, değişim içinde olan durumlara uyabilecek bir göç politikasının geliştirilmesi için çalışmalar günümüzde hala devam etmektedir. Bu yenilenme sürecinin önemi, Suriyeli göçmenlerin Avrupa Ülkelerine göç etmeleri ile daha da önem kazanmış olup, $\mathrm{AB}$ nezdinde yeni stratejiler tartışılmaktadır. Ayrıca göçmenlerin sosyal ve ekonomik olarak dışlanmıșlıklarını azaltmak amacıyla Türkiye ile işbirlikleri geliştirilmeye çalışılmaktadır. Bu anlamda Avrupa Birliği tarafından Türkiye'de göçmenlerin eğitim almaları ve emek piyasasına girebilmeleri için ekonomik destek taahhütleri de söz konusudur.

Birlik bünyesinde sadece güvenlik algılamasına dayanmayan aktif bir göç politikası oluşturulmalıdır. AB vatandaşı olmadıkları için Birlik Müktesebatı'ndan faydalanamayan göçmene, sadece ekonomik alanda değil sosyal ve belirli ölçülerde siyasal alanlarda da firsat eşitliğinin tanınması için stratejiler geliştirilmelidir. Tüm yönleri ile bağlayıcı ve caydırıcı olan bir "Irkçılık ve Yabancı Düşmanlığıyla Mücadele Kararı" hazırlanmalıdır.

Devletlerin, göç politikaları ile ilgili problem endişesi yaratan noktaları, objektif şekilde ele alıp olumlu çözümler oluşturabilmek için iyi bir atmosfer oluşturması gerekmektedir. Halkın bu konu ile ilgili doğru bilgilendirilmesi ve politikaları anlaması için şeffaf, tutarlı ve halkı içeren konsept ile yürütülmesi gereklidir. Örneğin; devletler için sadece geçici göçmen aldığını söylemesi sosyal atmosfer için iyi olmayacaktır, çünkü bu göçmenlerin sürekli ikamet hakkı elde etme taleplerini önleyemeyecekleri bilinmektedir.

Avrupalı ve diğer ülkeler göçmenlere karşı algılarını değiştirmedikleri müddetçe, göçmenlerin etkin bir şekilde entegrasyonu mümkün olamayacaktır. Göçmenler sorunlu, güvenlik tehdidi veya bir yük olarak görüldüğü takdirde, tepkici politikaların çıkarılması yönünde toplumsal zemin oluşacaktır. Eğer bu ülkeler istekli bir biçimde göçmenlerin entegrasyonuna gayret gösterirlerse, 
Yalova Sosyal Bilimler Dergisi

toplumun tüm kesimleri faydalanacaktır. Hatta bu süreçte geldikleri ülkelere gönderdikleri paralar sayesinde kaynak ülkenin de faydalanması sağlanacaktır.

$\mathrm{AB}$ içerisinde son yıllarda iktidara gelen Hıristiyan Demokratlar ve Milliyetçi partiler nedeniyle, özgürlükçü Avrupa algısı giderek zayıflamaktadır. Hatta giderek sertleșen güvenlik önlemleri bu düşünceyi daha da pekiştirmektedir. Dolayısıyla, AB'nin bu algıdan kurtulması amacıyla çok kültürlülüğü teşvik etmesi ve bir Hıristiyan kulübü gibi görünmemesi için farklı dinlerden göçmenlere kapılarını rahatıkla açmalı ve o din mensuplarının yaşam alanları bulmalarını kolaylaştırmalıdır.

Avrupa Birliği'nin gelmiş olduğu noktada, Birlik üyeleri arasında ortak bir politikanın belirlenmesi önem kazanmıştır. Ancak Birliğin birtakım kararları alırken veya göçmenler ile ilgili politikaları oluştururken sadece üye ülkelerin değil, ayrıca komşu ve hatta komşu olmayan ancak göç alma ihtimali olan bölgelerin ve ülkelerin dikkate alınması gerekmektedir. Yani göç meselesini yalnızca Birlik meselesi olarak değerlendirmek yerine, göç veren kaynak ülkelerinde sorunu olarak görmek ve politikaların üretilme sürecine onları da katmak başarı şansını artıracaktır. Sadece ekonomik göçmenler için değil tüm göçmenlerinde aynı haklara sahip olması sağlanmalıdır. Hatta Birlik vatandaşlarına tanınan hakların tanınması, evrensel açıdan uygun bir uygulama olacağı gibi göçmenlerin içerilmeleri yönüyle de anlamlı olacaktır. Dolayısıyla, göç kontrolü yerine göç politikaları, güvenlik yerine entegrasyon anlayışı benimsenmelidir.

\section{Kaynakça}

Apap Joanna, (2001). "Shaping Europe's Migration Policy: New Regimes for the Employment of Third Country Nationals: a Comparison of Strategies in Germany, Sweden, the Netherlands and the UK" - Centre for European Policy Studies.

Berlinghoff, Marcel, (2007). Migration and Cultural Integration in Europe, ifaEdition Culture and Foreign Policy, Conference Report, Brussels, 11 December 2013Bertozzi Sandro, "Legal Migration, A Time for Europe to Play Its Hand" CEPS Working Document No. 257/February.

Bingöl, Aslıhan Selcen, (2006). Almanya ve Hollanda'da Türk Göçmen İşçi Çocuklarına Dönük Eğitim Politikaları ve Uygulamaları, Gazi Üniversitesi Eğitim Bilimleri Enstitüsü Eğitim Bilimleri Anabilim Dalı Eğitimin Sosyal ve Tarihi Temelleri Yüksek Lisans Tezi, Ankara.

Collett, Elisabeth, (2011). Immigrant Integration in Europe in a Time of Austerity. Migration Policy Institute, http://www.migrationpolicy.org/research/TCMimmigrant-integration-europe-time-austerityCrowley, Niall. 2010, Hidden Messages, Overt Agendas. Dublin: Migrant Rights Centre Ireland, http://www.mrci.ie/media/128716146816_OVERT_AGENDAS.pdf

Czech Government, (2009). Report on the Integration of Foreigners 2009. Prague: Czech Goverment. 
Yalova Sosyal Bilimler Dergisi

Çalışma ve Sosyal Güvenlik Bakanlığı AB Koordinasyon Dairesi Başkanlığı Bülteni (ABKDBB), (Haziran 2006): “Göç Avrupa'da Başlıca Yoksulluk Riski Unsuru", Say1 13.

Davis, Andrew, (2008). Multi-nation building? Immigrant integration policies in the autonomous communities of Catalonia and Madrid. London: The Canada Blanch Centre for Contemporary Spanish Studies, London School of Economics and Political Science.

Değirmenci, Gamze, (2011). Avrupa Birliği Göç Politikası Kapsamında Fransa'nın Göç Politikası, İstanbul Üniversitesi, Sosyal Bilimler Enstitüsü Avrupa Birliği Ana Bilim Dalı, Yüksek Lisans Tezi, İstanbul.

Ertan, Serkan, (2007). Almanya'da Irkçılık ve Antisemitizm, Ankara Üniversitesi, Sosyal Bilimler Enstitüsü, Avrupa Birliği Uluslararası Ekonomik İlişkiler Anabilim Dalı, Yüksek Lisans Tezi., Ankara.

Ertem, Haşim Emre,(2007). Illegal Immİgratİon to EU Countrıes; New Asylum Policies In Spain and Germany, Marmara Universitesi Sosyal Bilimler Enstitüsü Sosyal Bilimler ve Uluslararası İlişkiler Anabilim Dalı,Yüksek Lisans Tezi, İstanbul.

Ecre, European Council on Refugees and Exiles, Çevrimiçi, 07.02.2016, http://www.ecre.org/topics/areas-of-work/introduction/39-integration.htm

European Commission , (2010). Europea Economic Forecast: Autumn 2010. Brussels:

http://ec.europa.eu/economy_finance/publications/european_economy/201 0/pdf/ee-2010-7_en.pdf

European Commission,(2002). "The Social Situation in the European Union, 2002", Brussels.

Fuller, Thomas, (2002). "Foreign workers Face Turning Tide: Backlash in Europe", in International Herald Tribune, 24.12.2002

Gençler, A., (2005). “Avrupa Birliğinin Göç Politikası”, Sosyal Siyaset Konferansları, Prof.Dr. Turan Yazgan'a Armağan Özel Sayısı 49. Kitap İstanbul Üniversitesi Yayın No:4566, İktisat Fakültesi Yayın No:582,173198 (2005).

Hermann, Helga; (1993). "Ursachen und Entwicklung der Ausländerbeschäftigung”, Informationen zur Politischen Bildung, Nr: 237, 4. Quartal.

HM Treasury, (2010). Spending Review 2010, London: HM Treasury. http://cdnhtreasury.gov.uk/sr2010_completereport.pdf

Irish Department of Finance, (2007). Budget Estimates 2008. Dublin: Department of Finance.

J, Salt \& J, Stein, (1997). 'Migration as a business: the case of trafficking', International Migration, 35 (4), p. 467-494. 
Yalova Sosyal Bilimler Dergisi

Karakuş, Mine, (2007). "Integration of The Immigrant Youth in Germany", European Studies M.A. Thesis, February.

Karaşahin, Murat, (2012). Avrupa Birliği’nde Ortak Göç Politikası Oluşturma Çabaları ve Ulusal Farklılıklar Sorunu, Gazi Üniversitesi Sosyal Bilimler Enstitüsü Uluslararası İlişkiler Anabilim Dalı Uluslararası İlişkiler Bilim Dal1, Ankara.

Köse, Sezen Ceceli, (2012). Çok Kültürlücülük Politikalarından Entegrasyon Politikalarına Geçiş: Hollanda'daki Türkiye Kökenli Göçmenler Üzerine Bir İnceleme, Hacettepe Üniversitesi Sosyal Bilimler Enstitüsü YL Tezi, Ankara.

M Baldwin-Edwards \& M Schain, (1994). 'The politics of immigration', West European Politics, 17 (2), 1994, p. 1-16.-a

Liebig, Thomas, (2007). The Labour Market Integration of Immigrants in Denmark. OECD Social, Employment and Migration Working Paper No: 50Paris: Organization for Economic Cooperation and Development.

McCabe, Kristen, et.all. (2009). Pay to go: Countries Offer Cash to Immigrants Willing to Pack Their Bags. Migration Information Source, November 2009. http://www.migrationinformation.org/Feature/display.cfm?ID=749

Nyberg-Sorenson Ninna, Van Hear Nicholas, Engberg-Pedersen Poul, (2002). "The MigrationDevelopment Nexus Evidence and Policy Options" International Organisation for Migration, July

Peutrell, Rob, (2010). Coalition announces cuts in ESOL funding, News release, Institute for Race Relations, December 16, 2010, www.irr.org/2010/december/ha000017.html

Penninx, R., Spencer, D. And Hear, N.V. (2008). Migration and Integration in Europe: The State of Research. ESRC Centre on Migration, Policy and Society (COMPAS) University of Oxford.

Portuguese Presidency of the Council of Ministers. (2010). Resolution of the council of Ministers, No.74/2010, Second Plan for Immigrant Integration (2010-2013). Lisbon: Presidency of Council of Ministers. http://www.acidi.gov.pt/_cfn/4d346c9b80687/live/Resolu\%E7\%E3o+de+C onselho+de+Ministros+n\%BA74\%2F2010.

Silaşi, Grigore, Rollet Phillipe, Trandafir Nicu, Vădăsan Ioana (2006)."Economia Uniunii Europene: o poveste de succes?" - Editura de Vest, Timişoara,

Somerville, Wil,. (2007). Immigration under New Labour. London: Policy Press.

Sweden, Sweedish Ministry of Integration and Gender Equalit, (2010). New Policy for the introduction of newly arrived immigrants, Stockholm: Ministry of Integration and Gender Equality, www.sweden .gov.se/sb/d/12485/a/157688

Sutherland, Peter, (2016). A Beter Year for Migrants, Project Syndicate, Jan 7, Çevrimiçi 07.02.2016, www.project-syndicate.org 
Yalova Sosyal Bilimler Dergisi

Snyder, Loni Diane, (2006). The New "Integration" Tests and Materials in the Netherlands, Germany, Baden-Wurttemberg, and the United Kingdom: The Muslim Other and The Change From Multiculturalism to Assimilation", Master Thesis, Bosphorus University

Tekin, Mustafa, (2009). Türkiye'de Yaşayan Sığınmacı VE Mültecilerin Entegrasyonunda Yaşanan Sorunlar ve Avrupa Birliği Uygulamaları Bağlamında Çözüm Önerileri, Polis Akademisi Güvenlik Bilimleri Enstitüsü Uluslararası Güvenlik Anabilim Dalı, Yüksek Lisans Tezi, Ankara.

The Economist, (2016). "A Plan For the Refugees How to manage the migrant crisis", February 6th 2016.

Tuncer, A., (2012). Federal Almanya'nın Avrupa Birliği Bölgesel Politikalarının Oluşumundaki Etkisi, Uluslararası İnsan Bilimleri Dergisi, Erişim: http://www.insanbilimleri.com

Uitermark, Justus, (2014). Integration and Control: The Governing of Urban Marginality in Western Europe, International Journal of Urban and Regional Research 38.4, Volume 38. 1418-36.

www.ue.eu.int 